\title{
Assessing planning impact on time and cost in Construction projects
}

\section{Adel Uoenes Mohamed Abd El-Rahman a, Ali Fathy Eid b, Hazem Eldaly c}

A Master Student, Dept. of Architecture, Faculty of Engineering, Ain Shams University in Egypt

b Professor, Dept. of Architecture, Faculty of Engineering, Ain Shams University in Egypt

c Professor, Dept. of Architecture, Faculty of Engineering Ain Shams University in Egypt

\begin{abstract}
The construction projects in Egypt Exposed to risk because the impact of planning not based on the knowledge or full data of the project parameters, it will lead to the timeline implementation of the project will not be as planned.

Research objectives: support the main objective of the project management includes (time - quality - cost) that is the main reason for the success of any project.

The research method includes the theoretical methodology and practical methodology.

The theoretical methodology includes the definition of project management's method shortcut in general, construction projects less knowledge and data of engineering planning method within stakeholders includes such as owners, project management team, and consultant.
\end{abstract}


The practical methodology going to be within comparing between three projects and found out the reasons "why the project timeline affected and not been qualified?" one of the projects is economic housing is been late 10 years and been stopped of implementation which affects over buildings quality, analysis the results then work within statistics then came out with recommendations.

\section{Keywords:}

Engineering planning, Project management, Timeline, construction projects

\section{INTRODUCTION:}

Project planning means developing an executable vision for the operations that are being implemented to complete the project, and this stage includes defining the operations that must be implemented and the order in which they must be implemented, and this requires a deep knowledge of implementation methods with the ability to formulate the project in the form of separate work parts and determine the relationship between them, so this task should be performed by individuals who have significant experience working on the implementation sites.

\subsection{Structure:}

Research structure gathering data built over six chapters

- Chapter One: Definition and strategies

- Chapter Two: lecture

- Chapter Three: the process of management of economic housing

- Chapter Four: the method and artificial intelligence

- Chapter Five: case studies

- Chapter Six: discussion and recommendation 


\subsection{Tables:}

Table 1: Explains the price increase in a residential project in Burj Al Arab - Alexandria, due to the delay in the project period for the specified time, and this is some of the applied studies of the research

\begin{tabular}{|c|c|c|c|}
\hline \multirow{3}{*}{ Item } & \multicolumn{2}{|c|}{ The price of the item } & \multirow{3}{*}{$\begin{array}{c}\text { The } \\
\text { increa } \\
\text { se rate }\end{array}$} \\
\hline & $\begin{array}{c}\text { Before } \\
1 / 4 / 2014\end{array}$ & $\begin{array}{c}\text { After } \\
1 / 4 / 2014\end{array}$ & \\
\hline & $\begin{array}{l}\text { The original } \\
\text { price }\end{array}$ & $\begin{array}{l}\text { The original } \\
\text { price }\end{array}$ & \\
\hline excavation & Is 15.24 & 20.96 & $38 \%$ \\
\hline Replacement & 95.25 & 120.65 & $27 \%$ \\
\hline Backfilling sand & 52.71 & 82.55 & $57 \%$ \\
\hline PCC concrete for foundations & 502.92 & 609.60 & $21 \%$ \\
\hline $\begin{array}{l}\text { Normal concrete compacting for the Ground } \\
\text { Floor }\end{array}$ & 0.00 & 87.63 & \\
\hline Concrete for slope surfaces & Lost 24.13 & 43.18 & $79 \%$ \\
\hline Reinforced concrete foundations & 1286.51 & $1,386.31$ & $14 \%$ \\
\hline Reinforced concrete for columns & 1816.10 & 2159.00 & $19 \%$ \\
\hline Reinforced concrete for Staircase structure & 1889.76 & 2235.20 & $18 \%$ \\
\hline Reinforced concrete for slabs 20 & 308.16 & soared370.46 & $20 \%$ \\
\hline The supply and fix block work of $20 \mathrm{~cm}$ & 571.50 & 744.22 & $30 \%$ \\
\hline The supply and fix block work of $10 \mathrm{~cm}$ & Le57.15 & 82.55 & $44 \%$ \\
\hline $\begin{array}{l}\text { The supply, paint of foundations surface two } \\
\text { bitumen layer }\end{array}$ & $\$ 16.38$ & 21.59 & $32 \%$ \\
\hline Insulation the bathrooms floors & 0.00 & 85.09 & \\
\hline Roof flooring Insulation & 33.55 & 55.88 & $66 \%$ \\
\hline $\begin{array}{l}\text { The supply and painting of the internal walls and } \\
\text { ceilings bathrooms and kitchens }\end{array}$ & 22.23 & 34.29 & $54 \%$ \\
\hline Ceiling paint including fixing fiber mesh & 22.10 & 35.56 & $61 \%$ \\
\hline Painting spray plaster for elevation front sides & 44.45 & 73.66 & $66 \%$ \\
\hline Painting staircases and corridors & 0.00 & 63.50 & \\
\hline Stairwell painting & 0.00 & 66.68 & \\
\hline Ceramic Floors for Apartments & 0.00 & 95.52 & \\
\hline Ceramic floors for bathrooms and kitchens & 0.00 & 85.09 & \\
\hline Ceramic walls of the kitchens and bathrooms & 0.00 & 82.55 & \\
\hline Cement tiles for roofs & 0.00 & 64.77 & \\
\hline
\end{tabular}




\begin{tabular}{c|c|c|c}
\hline Threshold marble for staircases and corridors & 0.00 & 177.80 & \\
\hline staircases steps marble & 0.00 & 152.40 & \\
\hline Oil Painting ceiling for bathrooms and kitchens & 0.00 & 25.40 & \\
\hline plastic paint walls and ceilings & 0.00 & 24.13 & \\
\hline The doors of the apartments & 901.70 & 1201.42 & $33 \%$ \\
\hline The doors of the rooms & 723.90 & 971.55 & $34 \%$ \\
\hline The doors of the bathrooms & 703.58 & 902.97 & $28 \%$ \\
\hline The doors of the balconies & 516.26 & 746.76 & $45 \%$ \\
\hline The windows of the elevation interfaces & 516.26 & 775.97 & $50 \%$ \\
\hline Balcony handrail & 177.80 & 213.36 & $20 \%$ \\
\hline
\end{tabular}

\subsection{Illustrations:}

Figure 1 A detailed description of the project's resource management

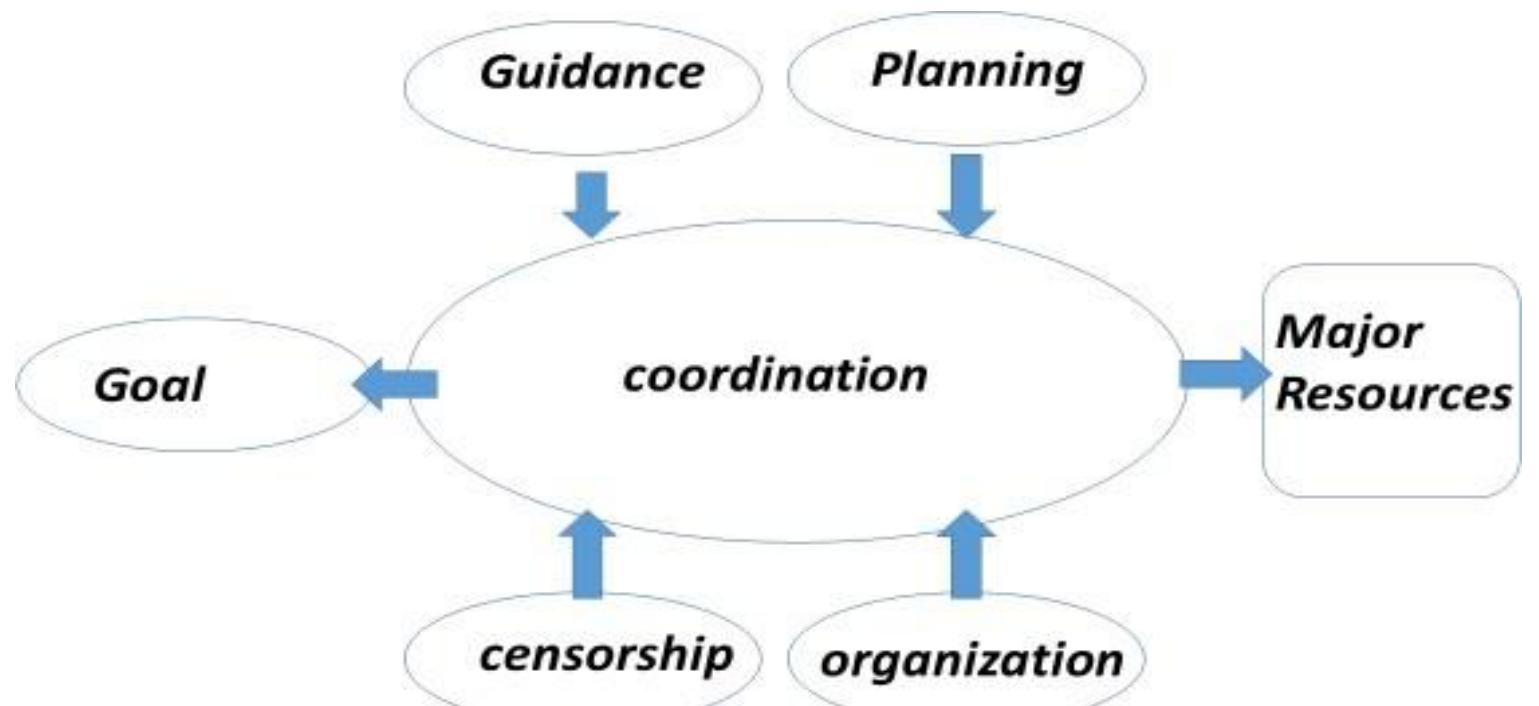

\section{MATERIALS AND METHODS:}

The theoretical methodology includes the definition of project management's method shortcut in general, construction projects less knowledge and data of engineering 
planning method within stakeholders includes such as owners, project management team, and consultant.

The practical methodology going to be within comparing between three projects and found out the reasons "why the project timeline affected and not been qualified?" one of the projects is economic housing is been late 10 years and been stopped of implementation which affects over buildings quality, analysis the results then work within statistics then came out with recommendations.

\section{RESULTS AND DISCUSSION:}

1-The case study shows that there is a strategic imbalance in a large number of construction companies led to the delay in completion of projects, this imbalance was clear when found these companies themselves in a real crisis resulting from the inability to implement their plans on the project as a result of the lack of planning culture, and lack of understanding of the technical staff in the project of the nature of the engineering project, and therefore the utilizing of project resources in the wrong place which led to their further delay.

2-The study showed the existence of administrative imbalance in contracting companies in ignoring the importance of planning, which inflicted the chaos and proved that inflexibility in dealing with the project risks and the lack of administrative coordination between the cadres of the project on the one hand and the company on the other hand which push such companies to carry out uncalculated steps led to further delayed projects rather than reducing the time of completion.

3-The study showed the clear weakness in the contracting companies in the field of planning in terms of their capacity to develop a precise scheduled program for the project which caused the errorin assessment the completion period of the project where these companies did not distinguish between the business-critical and non-critical situation in the implementation of the project plan which confirms the lack of time management of these companies. 
4-The study showed that contracting companies depend on Generics in their plans without a focus on the real objectives of the project, which is the completion of the project as soon as possible withthe best quality and less expensive, and therefore the failure of the project plan, which entailed the waste of time and money.

5-The study showed the existence of a structural imbalance in the senior hierarchy in contracting companies where these departments are not applying the principle of compulsory planning, allowing the company's cadres in the implementationof modern scientific applied in the field of management and planning of construction projects; whichled to the delay in the project cadre in critical decisions during the project and therefore further waste at the time of implementation.

\section{CONCLUSION:}

1. Construction companies have to specify a special section within the core of their divisions to carry out the extensive study of the project drawings and all its documents from public and private specifications and contracts so that these companies will be able to understand the nature of the project and analyzing data and determine the objectives of the project

2-construction companies have to hire the right candidates that are well trained and professional in the field of planning and implementation, even if mandated that pay high wages to these cadres and that these companies give planning a major priority by allowing engineers planning the company's participation in the decisions making and technical issues.

3-construction companies have to delegate authority to the concerned staff who in turn distribute the work and allocation of resources to this business, and that planning Department will allow the company to employees with experience to participate in the development of plans

4-construction companies have to maintain periodic meetings between planners and implementers, by which to explain the plans and objectives for employees in the company and explain any changes that may occur 
5-Construction companies have to develop training for managers \& technicians to training courses, each according to their competence like (PMP) and also subjected to periodic tests by professional parties and certified once to ensure the permanent process of planning and implementation readiness.

6-Construction companies have to prepare statistical data about previous projects for use in futureprojects databases.

7-Construction companies have to support the tenders section by all the modern means and qualified personnel, to be able to estimate the cost of projects with high precision, which avoids falling into financial crises.

8-Construction companies have to rely on modern computer software in the field such as project planning (primavera) which saves money and effort.

9-Construction companies have to activate the role of the risk management department so they can easily face emergency work during the period of implementation of the project.

10-construction companies have to activate the rewarding system especially for encouraging the daresspecialized in the planning and assigning of financial awards to these cadres in case of the success of their plans and the application of the bonus system for the early completion of the projects.

11-Construction companies encourage their employees to the optimal use of time and develop theirskills in time management and linking time with other factors that contribute to the success of the project and is the cost and quality.

12 - Construction companies have to coordinate with each other through a formal affiliation with associations such as the society of engineers and contractors' Association, to exchange experience and discuss problems between these companies and therefore find appropriate solutions to these problems. 
13-Constructions companies have to send their skilled employees to the massive companies to benefit from the expertise and the transfer of this experience, and that these companies must establish a special section for the training and development to transfer the experience of its employees in an Academy manner.

14- Construction companies have to keep entertainment programs for their staff to reduce apathy in the determination of their employees as a result of standard routine at work.

15- Construction companies have to set policies and regulations related to decision-making and develop these policies for public interests, which saves time for the decision-maker in making sound decisions.

16-Construction companies have to circulate the following the scheduled program for the project is the only way to complete this project on time.

17-Contracting companies have to be sure of taking all of the approvals from authorized parties before the date of the commencement of the project.

18-the importance of tenders in awarding the projects and stop giving projects directly to companies, in the case of necessity to assign the direct order must be the completion of the identification and analysis of all prices before the commencement of the project

19- Exchange of experience and bound together to gain the rights of the contracting companies against different parties especially in the conditions beyond of their wil. 


\section{References:}

- Prof. Dr. Adel Al-Samdouni, Prof. Dr. Osama Ahmed Hosni, Dr. Hani Al-Sawah, Construction Department, Helwan University, Matareya Engineering, 1995 AD.

- The Egyptian Code, Construction Projects, Ministry of Housing, National Research Center for Housing and Building, First Edition 2009.

- Dr. Muhammad Al-Sayrafi, Time Management, Horus International Foundation, 2006 AD.

- Translated by Walid Shehadeh, Time Management, Milesyarafunni, Harvard Business School Publications, 2007 AD.

- Eng. Khaled Abdel Aal, Primavera Handicrafts Department, www.elecgate.com Business Principles book. Ain Shams Ahmed Sorour Mohamed Library, 1980

- A guide for using the primavera program for digital printing, and the guide, scientific books for publishing and distribution Cairo 2003.

- Administrative Expenses Management Book - Naim Naseer, Arab Administrative Development Organization, Cairo 2003.

- Book of principles of management between theory and practice d. Muhammad Ismail Bilal, New University House for Publishing, Alexandria 1999.

- Eng. / Mohamed Ezzat Ahmed, Food Planning and Management Using Primavera, Computer Science Facilitation Series, 2000 AD.

- Dr. Abdel Salam Zidan, A Simplified Guide to Using MS Project, www.zidan.com, 2005.Dissertations and Research:

- Eng. Emad Fouad Georgy Mikhael, Program and Jobs 
Management and their Impact on Construction Projects Implementation, Master Thesis, Faculty of Engineering, Ain Shams University, 2015 AD.

- Master's thesis at the Faculty of Fine Arts, Department of Décor (2006), entitled: - (Interior Fine Arts Management). Foreign websites and messages:

\section{Internet sites:}

- https://www.officena.net/ib/topic/16954-\%D9\%83\%D9\%84\%D8\%B4\%D9\%89\%D8\%A1-

- \%D8\%B9\%D9\%86-\%D8 \% A8\% D8\% B1\% D9\% 86\% D8\% A7\% D9\% 85\% D8\% AC-ms-project 